\title{
Estrogen Receptors in Leukocytes - Possible Impact on Inflammatory Processes in the Female Reproductive System
}

\author{
Chellakkan Selvanesan Blesson \\ Karolinska Institutet \\ Sweden
}

\section{Introduction}

Estrogens carry out various reproductive and non-reproductive functions. Traditionally, estrogen action was thought to be solely mediated through its nuclear receptors - estrogen receptor (ER)a and ER $\beta$ (Deroo \& Korach, 2006). However, recently a membrane bound G protein-coupled receptor-30, now designated as G protein-coupled estrogen receptor1(GPER), has been described as a receptor for estrogen (Prossnitz et al., 2007). ERa and ER $\beta$ belong to the nuclear receptor superfamily and functions as ligand activated transcriptional factors. The classical mechanism of nuclear ER action involves ligand binding to receptors, dimerization and binding to specific response elements of the target genes to elicit a transcriptional response. Although estrogen action is mostly targeted towards reproductive tissues, they also act via ERs in non-reproductive target tissues (Diel, 2002; Manolagas \& Kousteni, 2001; Walker \& Korach, 2004). Estrogens can also act rapidly through nongenomic mechanisms by binding to membrane bound ERs (Deroo \& Korach, 2006; Prossnitz et al., 2007). GPER is a member of the $G$ protein-coupled receptor superfamily containing seven transmembrane helices and mediates estrogen-dependent kinase activation as well as transcriptional responses (Prossnitz et al., 2007). Receptors for estrogens are present in leukocytes and perform various functions. ERs and several of their splice variants have been identified in polymorphonuclear and mononuclear leukocytes isolated from peripheral blood of both men and women (Stygar et al., 2006). ERs are present in a variety of leukocytes like myeloid progenitor cells, neutrophils, lymphocytes, natural killer cells, macrophages, monocytes, mast cells etc. This chapter will summarize the publications on the role of estrogen in leukocytes and its implications in female reproduction.

\section{Estrogen receptors in leukocytes}

Leukocytes play a key role in several physiologically important processes like immunity, inflammation, extracellular matrix remodeling, wound healing, cardiovascular disorders, autoimmune diseases, menstruation, embryo implantation, cervical ripening, labor etc. They are involved in various functions during normal as well as pathological conditions. Estrogens act on leukocytes and influence their number and function (Bouman et al., 2005). In recent years, several investigations have focused on the action of estrogens in the immune 
system and inflammation. Clinical, epidemiological and immunological studies have shown that women are more prone to autoimmune disorders in comparison to men. Studies have shown that the incidence of cardiovascular disease is higher in men than in women and the incidence in women increases towards the level of men after menopause. There is clear sex bias in the disease presentation. Estrogens have been suggested to be responsible for these differences (Cutolo et al., 2010; Druckmann, 2001; Nalbandian \& Kovats, 2005). These diseases are often associated with leukocyte infiltration and immune dysfunction. It has been hypothesized that estrogens alter the course of these disorders by modulating leukocyte function in various tissues. Although the exact mechanism by which estrogens modulates the immune cell function is not completely understood, these observations clearly show that leukocytes are estrogen targets.

\subsection{Neutrophils}

Neutrophils are the most abundant type of leukocytes and form an essential part of the immune system. Klebanoff demonstrated that estrogens specifically bind to neutrophils using ligand binding experiments (Klebanoff, 1977). It was further shown that estrogens influence the neutrophil count and women have a higher neutrophil count than men (Bain \& England, 1975a). In women, the neutrophil number varies during the menstrual cycle (Bain \& England, 1975b; Smith et al., 2007). Higher levels of neutrophil counts correlate to the elevated levels of estradiol in peripheral blood (Mathur et al., 1979). Recent studies showed that ERs are present in neutrophils and execute various direct or indirect functions. It was shown that polymorphonuclear cells express both ERa and ER $\beta$ and their various splice variants (Molero et al., 2002; Stygar et al., 2007). Molero et al, demonstrated that estradiol up-regulated both ERa and ER $\beta$ in women but only ERa in men (Molero et al., 2002). The functional signaling of ERs in neutrophils was further established by the induction of nNOS by estradiol (Garcia-Duran et al., 1999). Further, estradiol and ER specific agonists regulated physiologically relevant genes in polymorphonuclear cells in rats (Stygar et al., 2007). Recently, we have identified the presence of GPER in terminally differentiated neutrophil like HL-60 cells. The GPER agonist G1 could stimulate a transcriptional response indicating that GPER is functionally active in these cells (Blesson and Sahlin, unpublished). Neutrophils have a very short life span and they stay in circulation for 6 to 18 hours before undergoing apoptosis. Estradiol along with progesterone increases neutrophil survival by delaying apoptosis via decreasing the activities of caspases 3 and 9 (Molloy et al., 2003). Estrogens may also have a vital role in the regulation of genes that are associated with the immune and inflammatory response, like chemokines and cytokines. These genes are responsible for neutrophil recruitment and activation during normal as well as pathological conditions (Jabbour et al., 2009; Straub, 2007).

\subsection{Lymphocytes}

Lymphocytes express nuclear as well as membrane estrogen receptors. Studies on human peripheral blood lymphocytes showed the presence of ERa and ER $\beta$ in various lymphocyte subsets including natural killer (NK) cells (Curran et al., 2001). A smaller variant of ERa called ERa 46 appears to be the most abundant isoform of ERs in lymphocytes. This variant was localized to the cell surface and mediates estrogen induced proliferation of T lymphocytes and NK cells but not B lymphocytes (Pierdominici et al., 
2010). ER $\beta$ is expressed predominantly in secondary lymphoid tissues and plays an important role in the peripheral immune system (Shim et al., 2006). Both ERa and ER $\beta$ are expressed in the NK cells of mice and humans (Curran et al., 2001). In mice, estrogens act via ER $\beta$ to suppress NK cell activity by altering their ability to lyse target cells (Curran et al., 2001). Estradiol induces the proliferation of splenic NK cells and suppresses the cytotoxicity of these cells (Hao et al., 2007). However, in vitro studies on murine NK cells showed that estradiol reduces NK cell proliferative capacity and reduces cytotoxicity by influencing cytokine expressions (Hao et al., 2008). In humans, the number of NK cells was significantly altered during the different phases of menstrual cycle. The NK cell population in the periovulatory phase when the estrogen level is high was twice that in other phases indicating a positive effect on its number (Yovel et al., 2001). The ER $\beta 1$ variant could be localized to uterine NK (uNK) cells (Henderson et al., 2003). Hence, estrogens could act directly on uNK cells via the ER $\beta 1$ receptor.

\subsection{Other mononuclear leukocytes}

ERs are also expressed in monocytes, macrophages, dendritic cells and mast cells. Both ERa and ER $\beta$ are present in monocytes and are able to regulate the expression of CD16 (Kramer et al., 2007). Estrogens can act on monocytes to modulate apoptosis and cell cycle progression (Thongngarm et al., 2003). Monocytes are responsive to estrogens and may be important in modulating the immune response (Scariano et al., 2008). These cells are recruited into damaged tissue and undergo differentiation to become macrophages or dendritic cells. In macrophages derived from a human primary monocyte culture, ERa and ER $\beta$ mRNA were detected. However, only the ER $\beta$ protein could be seen (Kramer \& Wray, 2002). Stygar and co-workers showed the presence of mRNA and protein of wild type ERa and ER $\beta$ and their splice variants in mononuclear cells purified from peripheral blood (Stygar et al., 2006). Recent reports have shown the presence of ERa and ER $\beta$ localized to the membrane and cytoplasm of macrophages derives from THP-1 cells (Subramanian \& Shaha, 2009). Estradiol was shown to regulate the expression of several genes related to macrophage activation and apoptosis (Kramer \& Wray, 2002; Subramanian \& Shaha, 2009). Further, plasma membrane associated ERa and cytosolic ER $\beta$ oppose the function of each other thereby promoting cell survival suggesting the importance of both receptors (Kramer \& Wray, 2002; Subramanian \& Shaha, 2009). A recent study showed that estradiol suppresses LPS induced NFkB activation in primary human macrophages (Murphy et al., 2010). These reports indicate that estrogen dependent ER signaling is necessary to perform various important activities in monocytes and macrophages. Estrogens act via ERa on myeloid progenitor cells to regulate their differentiation into dendritic cells by increasing expression of the transcription factor IRF4 (Carreras et al., 2010). It has also been reported that estradiol may strengthen innate immunity by enhancing interferon- $\gamma$ production in dendritic cell suggesting an active role played by ER in these cells (Siracusa et al., 2008). ERs have also been localized in mast cells (Zhao et al., 2001). In mast cells, estradiol acts via a membrane bound ERa and regulates calcium influx, which is a non-genomic signaling mechanism (Zaitsu et al., 2007). Estradiol also enhances IgE-dependent mast cell activation, resulting in a shift of the allergen dose response (Zaitsu et al., 2007).

These observations clearly show that in addition to their role in reproduction, estrogens appear to influence the immune system by targeting leukocytes. The presence of ERs 
indicates that estrogens could act directly on these cells regulating cellular functions. It could also explain the sexual dimorphism in the immune and inflammatory response.

\section{Leukocyte mediated estrogen action in reproduction}

Many normal female reproductive processes show classical signs of inflammation. It is now widely accepted that ovulation, menstruation, implantation, pregnancy, cervical ripening and parturition are governed by inflammatory processes. These events are often associated with expression of an array of inflammatory mediators including various cytokines and chemokines (Jabbour et al., 2009). Leukocytes are present in substantial numbers in the female reproductive tract and sex hormones directly or indirectly play a role in the recruitment and activation of these cells (Wira et al., 2010). Abnormal activation of inflammatory pathways leads to various pathological conditions like menstrual disorders, infertility, pregnancy loss, complicated labor, unripe cervix, reproductive tract cancers etc. (Jabbour et al., 2009). It appears that there is a coordinated attempt by the immune system to protect, maintain and repair the reproductive organs to perform its normal functions.

\subsection{Reproductive cycle}

The female reproductive cycle is highly controlled by reproductive hormones from hypothalamus, pituitary and ovary. The ovarian steroids not only perform their primary reproductive functions but are also involved in various functions related to immunity and inflammation. Innate and adaptive immunity are active throughout the menstrual cycle and ovarian estrogens act on epithelial cells and leukocytes of the female reproductive tract to offer protection against infection (Wira et al., 2010). Infiltration of leukocytes into the ovary is essential for ovulation. The invading leukocytes secrete proteases to weaken the follicular wall and thus aiding ovulation (Oakley et al., 2010). These leukocytes include macrophages and lymphocytes (Oakley et al., 2010). Leukocytes are present in great numbers and diversity in the reproductive tract throughout the reproductive cycle. The human endometrium undergoes constant remodeling during the course of the menstrual cycle and is infiltrated by leukocytes. A variety of leukocytes including uNK cells, neutrophils, eosinophils, lymphocytes, macrophages and mast cells invade endometrium (Salamonsen \& Lathbury, 2000). Endometrial remodeling involves inflammatory factors like cytokines, chemokines and prostanoids (Jabbour et al., 2009). Estrogens regulate the inflammatory process in the endometrium which involves influx of leukocytes (King \& Critchley, 2010). Infiltrating leukocytes not only provide protection against pathogens but also actively participate in the degradation and subsequent regeneration of endometrial tissue by secreting various proteases, cytokines and chemokines (Guo et al., 2011; Lathbury \& Salamonsen, 2000). Various proteases like tryptase, chymase, chymotrypsin plasminogen activator, elastase, heparanase, cathepsin G, $\beta$-glucuronidase, aryl sulphatase, metalloelastase and several metalloproteases are secreted and regulated by leukocytes, thereby playing an active role in tissue degradation prior to menstruation (Salamonsen \& Lathbury, 2000). Leukocytes also participate during the process of regeneration of the endometrium. Endometrial regeneration is an estrogen dependent process and the repair begins with the restoration of glands, stroma and epithelium along with endometrial angiogenesis. Leukocytes are abundantly present and could participate in the endometrial 
rebuilding process (Salamonsen \& Lathbury, 2000). Neutrophils are present in large numbers during endometrial repair and play an important role. In a mouse model designed to mimic the events of menstruation, it was observed that when neutrophils were depleted, endometrial regeneration was severely affected suggesting that neutrophils along with the regulatory factors they produce contribute to the tissue repair (Kaitu'u-Lino et al., 2007). Macrophages, eosinophils and lymphocytes could also contribute in this process (Salamonsen \& Lathbury, 2000). In humans, different subpopulations of leukocytes are present during the menstrual, proliferative, mid-secretory, and late-secretory phases (Jones et al., 2004). Certain chemokines like MDC, MCP-3, and FKN are abundant throughout the cycle. During the menstrual phase, IL-8 and HCC-4 mRNAs are up-regulated. In the proliferative phase, MIP- $1 \beta$, HCC-4, and eotaxin are up-regulated in glands and vessels of endometrium, whereas MIP-1 $\beta$, HCC-1, HCC-4 and 6Ckine were up-regulated during in the mid-secretory phase followed by the upregulation of HCC-1 and 6Ckine in the late secretory phase (Jones et al., 2004). It was also noticed that neutrophils, eosinophils and macrophages are present during menstrual phase, macrophages during proliferative phase, uNK cells, macrophages and $\mathrm{T}$ cells during mid-secretary phase and neutrophils, eosinophils and macrophages during late-secretory phase of the menstrual cycle (Jones et al., 2004).

\subsection{Implantation and decidualization}

A large number of leukocytes especially monocytes, macrophages and uNK cells infiltrate the implantation site, believed to be important modulators of trophoblast invasion and decidualization (Drake et al., 2001; Jones et al., 2004). If pregnancy does not occur another sub-population of leukocytes like neutrophils, eosinophils, and macrophages infiltrate and facilitate endometrial destruction (Jones et al., 2004). Decidualization is the process by which stromal cells differentiate into decidual cells. It involves an inflammatory type of reaction including leukocyte infiltration and cytokine production (Hess et al., 2007). Leukocytes are present in large amounts during decidualization indicating their participation in the process (Guo et al., 2011). Studies in mice showed that uNK cells promote uterine vascular cell remodeling that assist decidual growth (Blois et al., 2011). Certain uNK cell derived chemokines and cytokines can influence the gene expression profile of human endometrial fibroblasts in vitro suggesting that a similar mechanism could operate in the endometrium (Germeyer et al., 2009). uNK cells express ER $\beta$ and it may exert control over trophoblast invasion (Henderson et al., 2003; Kwak-Kim \& Gilman-Sachs, 2008). They also promote uterine vascular modifications assisting decidual growth during early pregnancy (Blois et al., 2011). Regulation of inflammation during implantation may follow a sequential model in which pro-inflammation is followed by anti-inflammation or there may be a continuous balance between the pro- and anti-inflammatory environments (Jabbour et al., 2009). These observations imply that there are interactions between different types of invading leukocytes and the factors that they secrete in the endometrium are important in order to bring about a successful implantation.

\subsection{Pregnancy}

The level of serum estrogens peaks during pregnancy and may reach more than a hundred fold to that of normal non-pregnant levels (Tulchinsky \& Hobel, 1973). At these high levels, estrogens can suppress many cytotoxic and innate immune responses, but stimulate 
antibody production, neo-angiogenesis and growth (Straub, 2007). Several chemokines and cytokines like TPO, VEGF, IL1a, ENA-78, IL-8, GM-CSF and GRO-a are upregulated in the first-trimester decidua (Segerer et al., 2009). These factors perform various functions including attracting a variety of leukocytes. Estrogens along with progesterone can regulate leukocyte number and activity. Studies indicate that neutrophils from women at term pregnancy have a significant delay in apoptosis inducing physiologic neutrophilia (Watson et al., 1999). This delay in apoptosis could be induced by estradiol and progesterone (Molloy et al., 2003). Along with the increase in neutrophil count, several metabolic changes including accumulation of myeloperoxidase take place in neutrophils to enhance cell metabolism and oxidant release during pregnancy (Kindzelskii et al., 2006; Muller et al., 2009). The symbiosis between mother and fetus during pregnancy is not due to immunological ignorance, but a complex transient modulation of the maternal immune response where the adaptive immunity is down-modulated and the innate immune response is enhanced (Muller et al., 2009). It has been reported that there is a temporary suppression of maternal $\mathrm{T}$ cell responses by arginase secreted by polymorphonuclear leukocytes in normal pregnancies (Kropf et al., 2007). Thus, there is interplay between the different types of leukocytes to protect the fetus from the maternal immune system. Early pregnancy also involves the action of dendritic cells. They control stromal cell proliferation, angiogenesis and the homing and maturation of NK cell precursors in the pregnant uterus (Blois et al., 2011). The number of uNK cells increase drastically during pregnancy. Precursors of $\mathrm{uNK}$ appear to be recruited from blood and this is promoted by rising levels of plasma estrogens and luteinizing hormone and limited by increasing progesterone (van den Heuvel et al., 2005). uNK cells promote vascular modifications during gestation which is vital for the formation of the placenta (Blois et al., 2011). Further, placenta and trophoblasts produce chemokines that may also recruit NK cells into the decidua during pregnancy (Chantakru et al., 2002; Drake et al., 2001).

\subsection{Cervical ripening and parturition}

Cervical ripening is an important event prior to parturition. It has been suggested that leukocytes could be responsible for the ripening of the cervix at term and these leukocytes express ERs (Junqueira et al., 1980; Osmers et al., 1992; Sahlin et al., 2008; Wang et al., 2001). Cervical ripening includes an inflammatory type of process and thus there is an infiltration of leukocytes. Both polymorphonuclear and macrophages migrate from blood vessels and accumulate in cervix before the onset of parturition (Osman et al., 2003; Stygar et al., 2001). The quantum of infiltrating leukocytes is modulated by inflammatory mediators like IL-8 and prostaglandins (Chwalisz et al., 1994; Luo et al., 2000). Cervical extracellular matrix is remodeled by the degradation of collagens and proteoglycans. Proteases like matrixmetalloprotease (MMP)-2 and MMP-9 were expressed during cervical ripening (Stygar et al., 2002). Cervical stromal fibroblasts and smooth muscle cells were identified as main sources of MMP-2, but MMP-9 protein was localized exclusively in invading leukocytes (Stygar et al., 2002). There are also reports showing that migrating leukocytes secrete collagenases that could play an important role in tissue remodeling during cervical ripening (Osmers et al., 1992). These data indicate the involvement of invading leukocytes in the cervical ripening process. It was observed that the influx of leukocytes were impaired in cervix of women post term not responding to prostaglandin priming, indicating that 
leukocytes are important for normal cervical ripening (Sahlin et al., 2008). Infiltrating leukocytes express ERs where estrogen may also act directly. ER $\beta$ expression in human cervix was significantly increased at term pregnancy when compared to non-pregnant controls, implying a role for ER $\beta$ in cervical ripening (Wang et al., 2001). Further, it was later shown that ER $\beta$ is expressed in invading leukocytes including macrophages (Stygar et al., 2001). In rats, estradiol and selective agonists regulate a number of genes related to inflammation and extra cellular matrix remodeling (Stygar et al., 2007). Thus ER $\beta$ might mediate the estrogen action leading to the activation of leukocytes facilitating cervical ripening. Leukocytes also infiltrate myometrium prior to parturition. Macrophages and neutrophils massively infiltrate the upper and lower segment of myometrium at term, suggesting that parturition is an inflammatory event (Thomson et al., 1999). Inflammatory genes are significantly regulated in human endometrium and cervix in association with parturition (Bollapragada et al., 2009). The inflammatory events are not limited to uterus and cervix but there are indications that peripheral blood leukocytes also actively participate in this process for a successful labor (Yuan et al., 2009). It has been suggested that inflammatory stimulus upregulate pro-inflammatory cytokines which may further upregulate prostaglandins, MMPs and attract leukocytes leading to myometrial contractility, rupture of membranes and cervical ripening (Challis et al., 2009).

\section{Inflammatory pathologies regulated by estrogen}

Abnormal regulation of the immune system could lead to various complications in female reproduction. Various autoimmune and inflammatory disorders have been reported (Cutolo et al., 2010; Deroo \& Korach, 2006; Jabbour et al., 2009; Straub, 2007). Estrogens have been implicated directly in diseases like arthritis, osteoporosis, systemic lupus erythematosus, multiple sclerosis, preeclampsia, complications in fertility, pregnancy loss, post-term labor, labor complications, cancers of breast and reproductive tract. Estrogens also play a vital role in the pathophysiology of female reproduction mediated by leukocytes. There are ample evidences to indicate that aberrant inflammatory pathways are directly or indirectly regulated by estrogens, contributing to the cause of various diseases.

\section{Conclusion}

Estrogens act through ERs and regulate various aspects of the immune system directly or indirectly acting through various downstream mediators. ERs have been found on diverse types of leukocytes. Estrogens act directly via its different receptors and regulate various inflammatory functions mediated through different types of leukocytes. Estrogens are also able to regulate the number, migration and function of leukocytes involving complex mechanisms. There are several clues and confirmations; however the exact nature, timing and interactions are still to be explored. Considering the recent findings of the function of estrogens in various aspects of immune regulation and inflammation, it is difficult to consider estrogens just as a 'female reproductive hormone' anymore. The role of estrogens in various inflammatory processes and its significance is well accepted. Estrogens regulate normal and pathological inflammatory events in reproduction. However, the molecular mechanisms of these events are still being worked out and demand more attention. 
Understanding the molecular mechanisms will enable us to know more about the normal and aberrant regulation of these reproductive events involving inflammation and their mediators. Both ERa and ER $\beta$ have several splice variants lacking different domains with possible different functions. The expression of these variants in different types of leukocytes is not known and warrants further investigation. With the identification of the new membrane bound GPER, the signaling mechanism has yet another layer of complexity and its presence or role in most of the leukocytes are yet to be established. Insights into the function and regulation of ERs in leukocytes could open up new possibilities for treatments for various diseases involving inflammation.

\section{Acknowledgements}

I wish to thank Dr. Lena Sahlin for her valuable comments on the manuscript. This work was supported by postdoctoral fellowships from Swedish Institute and The Swedish Research Council (Grant 20137) and research funding from Kronprinsessan Lovisas förening and Sällskapet Barnavård.

\section{References}

Bain, B. J. \& England, J. M. (1975a) Normal haematological values: sex difference in neutrophil count. British Medical Journal, Vol.1, No.5953, pp. 306-309, ISSN 00071447

Bain, B. J. \& England, J. M. (1975b) Variations in leucocyte count during menstrual cycle. British Medical Journal, Vol.2, No.5969, pp. 473-475, ISSN 0007-1447

Blois, S. M., Klapp, B. F. \& Barrientos, G. (2011) Decidualization and angiogenesis in early pregnancy: unravelling the functions of DC and NK cells. Journal of Reproductive Immunology, Vol.88, No.2, pp. 86-92, ISSN 1872-7603

Bollapragada, S., Youssef, R., Jordan, F., Greer, I., Norman, J. \& Nelson, S. (2009) Term labor is associated with a core inflammatory response in human fetal membranes, myometrium, and cervix. American Journal of Obstetrics and Gynecology, Vol.200, No.1, pp. 104 e101-111, ISSN 1097-6868

Bouman, A., Heineman, M. J. \& Faas, M. M. (2005) Sex hormones and the immune response in humans. Human Reproduction Update, Vol.11, No.4, pp. 411-423, ISSN 1355-4786

Carreras, E., Turner, S., Frank, M. B., Knowlton, N., Osban, J., Centola, M., Park, C. G., Simmons, A., Alberola-Ila, J. \& Kovats, S. (2010) Estrogen receptor signaling promotes dendritic cell differentiation by increasing expression of the transcription factor IRF4. Blood, Vol.115, No.2, pp. 238-246, ISSN 1528-0020

Challis, J. R., Lockwood, C. J., Myatt, L., Norman, J. E., Strauss, J. F., 3rd \& Petraglia, F. (2009) Inflammation and pregnancy. Reproductive Sciences, Vol.16, No.2, pp. 206215, ISSN 1933-7205

Chantakru, S., Miller, C., Roach, L. E., Kuziel, W. A., Maeda, N., Wang, W. C., Evans, S. S. \& Croy, B. A. (2002) Contributions from self-renewal and trafficking to the uterine NK cell population of early pregnancy. Journal of Immunology, Vol.168, No.1, pp. 2228, ISSN 0022-1767 
Chwalisz, K., Benson, M., Scholz, P., Daum, J., Beier, H. M. \& Hegele-Hartung, C. (1994) Cervical ripening with the cytokines interleukin 8 , interleukin 1 beta and tumour necrosis factor alpha in guinea-pigs. Human Reproduction, Vol.9, No.11, pp. 21732181, ISSN 0268-1161

Curran, E. M., Berghaus, L. J., Vernetti, N. J., Saporita, A. J., Lubahn, D. B. \& Estes, D. M. (2001) Natural killer cells express estrogen receptor-alpha and estrogen receptorbeta and can respond to estrogen via a non-estrogen receptor-alpha-mediated pathway. Cellular Immunology, Vol.214, No.1, pp. 12-20, ISSN 0008-8749

Cutolo, M., Brizzolara, R., Atzeni, F., Capellino, S., Straub, R. H. \& Puttini, P. C. (2010) The immunomodulatory effects of estrogens: clinical relevance in immune-mediated rheumatic diseases. Annals of the New York Academy of Sciences, Vol.1193, pp. 36-42, ISSN 1749-6632

Deroo, B. J. \& Korach, K. S. (2006) Estrogen receptors and human disease. Journal of Clinical Investigation, Vol.116, No.3, pp. 561-570, ISSN 0021-9738

Diel, P. (2002) Tissue-specific estrogenic response and molecular mechanisms. Toxicological Letters, Vol.127, No.1-3, pp. 217-224, ISSN 0378-4274

Drake, P. M., Gunn, M. D., Charo, I. F., Tsou, C. L., Zhou, Y., Huang, L. \& Fisher, S. J. (2001) Human placental cytotrophoblasts attract monocytes and CD56(bright) natural killer cells via the actions of monocyte inflammatory protein 1alpha. Journal of Experimental Medicine, Vol.193, No.10, pp. 1199-1212, ISSN 0022-1007

Druckmann, R. (2001) Review: female sex hormones, autoimmune diseases and immune response. Gynecological Endocrinology, Vol.15 Suppl 6, pp. 69-76, ISSN 0951-3590

Garcia-Duran, M., de Frutos, T., Diaz-Recasens, J., Garcia-Galvez, G., Jimenez, A., Monton, M., Farre, J., Sanchez de Miguel, L., Gonzalez-Fernandez, F., Arriero, M. D., Rico, L., Garcia, R., Casado, S. \& Lopez-Farre, A. (1999) Estrogen stimulates neuronal nitric oxide synthase protein expression in human neutrophils. Circulation Research, Vol.85, No.11, pp. 1020-1026, ISSN 0009-7330

Germeyer, A., Sharkey, A. M., Prasadajudio, M., Sherwin, R., Moffett, A., Bieback, K., Clausmeyer, S., Masters, L., Popovici, R. M., Hess, A. P., Strowitzki, T. \& von Wolff, M. (2009) Paracrine effects of uterine leucocytes on gene expression of human uterine stromal fibroblasts. Molecular Human Reproduction, Vol.15, No.1, pp. 39-48, ISSN 1460-2407

Guo, Y., He, B., Xu, X. \& Wang, J. (2011) Comprehensive analysis of leukocytes, vascularization and matrix metalloproteinases in human menstrual xenograft model. Public Library of Science One, pp e16840

Hao, S., Li, P., Zhao, J., Hu, Y. \& Hou, Y. (2008) 17beta-estradiol suppresses cytotoxicity and proliferative capacity of murine splenic NK1.1+ cells. Cellular $\mathcal{E}$ Molecular Immunology, Vol.5, No.5, pp. 357-364, ISSN 1672-7681

Hao, S., Zhao, J., Zhou, J., Zhao, S., Hu, Y. \& Hou, Y. (2007) Modulation of 17beta-estradiol on the number and cytotoxicity of NK cells in vivo related to MCM and activating receptors. International Immunopharmacolgy, Vol.7, No.13, pp. 1765-1775, ISSN 15675769 
Henderson, T. A., Saunders, P. T., Moffett-King, A., Groome, N. P. \& Critchley, H. O. (2003) Steroid receptor expression in uterine natural killer cells. Journal of Clinical Endocrinology and Metabolism, Vol.88, No.1, pp. 440-449, ISSN 0021-972X

Hess, A. P., Hamilton, A. E., Talbi, S., Dosiou, C., Nyegaard, M., Nayak, N., GenbecevKrtolica, O., Mavrogianis, P., Ferrer, K., Kruessel, J., Fazleabas, A. T., Fisher, S. J. \& Giudice, L. C. (2007) Decidual stromal cell response to paracrine signals from the trophoblast: amplification of immune and angiogenic modulators. Biology of Reproduction, Vol.76, No.1, pp. 102-117, ISSN 0006-3363

Jabbour, H. N., Sales, K. J., Catalano, R. D. \& Norman, J. E. (2009) Inflammatory pathways in female reproductive health and disease. Reproduction, Vol.138, No.6, pp. 903-919, ISSN 1741-7899

Jones, R. L., Hannan, N. J., Kaitu'u, T. J., Zhang, J. \& Salamonsen, L. A. (2004) Identification of chemokines important for leukocyte recruitment to the human endometrium at the times of embryo implantation and menstruation. Journal of Clinical Endocrinology and Metabolism, Vol.89, No.12, pp. 6155-6167, ISSN 0021-972X

Junqueira, L. C., Zugaib, M., Montes, G. S., Toledo, O. M., Krisztan, R. M. \& Shigihara, K. M. (1980) Morphologic and histochemical evidence for the occurrence of collagenolysis and for the role of neutrophilic polymorphonuclear leukocytes during cervical dilation. American Journal Obstetrics and Gynecology, Vol.138, No.3, pp. 273-281, ISSN 0002-9378

Kaitu'u-Lino, T. J., Morison, N. B. \& Salamonsen, L. A. (2007) Neutrophil depletion retards endometrial repair in a mouse model. Cell and Tissue Research, Vol.328, No.1, pp. 197-206, ISSN 0302-766X

Kindzelskii, A. L., Clark, A. J., Espinoza, J., Maeda, N., Aratani, Y., Romero, R. \& Petty, H. R. (2006) Myeloperoxidase accumulates at the neutrophil surface and enhances cell metabolism and oxidant release during pregnancy. European Journal of Immunology, Vol.36, No.6, pp. 1619-1628, ISSN 0014-2980

King, A. E. \& Critchley, H. O. (2010) Oestrogen and progesterone regulation of inflammatory processes in the human endometrium. Journal of Steroid Biochemistry and Molecular Biology, Vol.120, No.2-3, pp. 116-126, ISSN 1879-1220

Klebanoff, S. J. (1977) Estrogen binding by leukocytes during phagocytosis. Journal of Experimental Medicine, Vol.145, No.4, pp. 983-998, ISSN 0022-1007

Kramer, P. R., Winger, V. \& Kramer, S. F. (2007) 17beta-Estradiol utilizes the estrogen receptor to regulate CD16 expression in monocytes. Molecular and Cellular Endocrinology, Vol.279, No.1-2, pp. 16-25, ISSN 0303-7207

Kramer, P. R. \& Wray, S. (2002) 17-Beta-estradiol regulates expression of genes that function in macrophage activation and cholesterol homeostasis. Journal of Steroid Biochemistry and Molecular Biology, Vol.81, No.3, pp. 203-216, ISSN 0960-0760

Kropf, P., Baud, D., Marshall, S. E., Munder, M., Mosley, A., Fuentes, J. M., Bangham, C. R., Taylor, G. P., Herath, S., Choi, B. S., Soler, G., Teoh, T., Modolell, M. \& Muller, I. (2007) Arginase activity mediates reversible T cell hyporesponsiveness in human pregnancy. European Journal of Immunology, Vol.37, No.4, pp. 935-945, ISSN 00142980 
Kwak-Kim, J. \& Gilman-Sachs, A. (2008) Clinical implication of natural killer cells and reproduction. American Journal of Reproductive Immunology, Vol.59, No.5, pp. 388400, ISSN 1046-7408

Lathbury, L. J. \& Salamonsen, L. A. (2000) In-vitro studies of the potential role of neutrophils in the process of menstruation. Molecular Human Reproduction, Vol.6, No.10, pp. 899-906, ISSN 1360-9947

Luo, L., Ibaragi, T., Maeda, M., Nozawa, M., Kasahara, T., Sakai, M., Sasaki, Y., Tanebe, K. \& Saito, S. (2000) Interleukin-8 levels and granulocyte counts in cervical mucus during pregnancy. American Journal of Reproductive Immunology, Vol.43, No.2, pp. 78-84, ISSN 1046-7408

Manolagas, S. C. \& Kousteni, S. (2001) Perspective: nonreproductive sites of action of reproductive hormones. Endocrinology, Vol.142, No.6, pp. 2200-2204, ISSN 00137227

Mathur, S., Mathur, R. S., Goust, J. M., Williamson, H. O. \& Fudenberg, H. H. (1979) Cyclic variations in white cell subpopulations in the human menstrual cycle: correlations with progesterone and estradiol. Clinical Immunology and Immunopathology, Vol.13, No.3, pp. 246-253, ISSN 0090-1229

Molero, L., Garcia-Duran, M., Diaz-Recasens, J., Rico, L., Casado, S. \& Lopez-Farre, A. (2002) Expression of estrogen receptor subtypes and neuronal nitric oxide synthase in neutrophils from women and men: regulation by estrogen. Cardiovascular Research, Vol.56, No.1, pp. 43-51, ISSN 0008-6363

Molloy, E. J., O'Neill, A. J., Grantham, J. J., Sheridan-Pereira, M., Fitzpatrick, J. M., Webb, D. W. \& Watson, R. W. (2003) Sex-specific alterations in neutrophil apoptosis: the role of estradiol and progesterone. Blood, Vol.102, No.7, pp. 2653-2659, ISSN 0006-4971

Muller, I., Munder, M., Kropf, P. \& Hansch, G. M. (2009) Polymorphonuclear neutrophils and T lymphocytes: strange bedfellows or brothers in arms? Trends in Immunology, Vol.30, No.11, pp. 522-530, ISSN 1471-4981

Murphy, A. J., Guyre, P. M. \& Pioli, P. A. (2010) Estradiol suppresses NF-kappa B activation through coordinated regulation of let-7a and miR-125b in primary human macrophages. Journal of Immunology, Vol.184, No.9, pp. 5029-5037, ISSN 1550-6606

Nalbandian, G. \& Kovats, S. (2005) Understanding sex biases in immunity: effects of estrogen on the differentiation and function of antigen-presenting cells. Immunological Research, Vol.31, No.2, pp. 91-106, ISSN 0257-277X

Oakley, O. R., Kim, H., El-Amouri, I., Lin, P. C., Cho, J., Bani-Ahmad, M. \& Ko, C. (2010) Periovulatory leukocyte infiltration in the rat ovary. Endocrinology, Vol.151, No.9, pp. 4551-4559, ISSN 1945-7170

Osman, I., Young, A., Ledingham, M. A., Thomson, A. J., Jordan, F., Greer, I. A. \& Norman, J. E. (2003) Leukocyte density and pro-inflammatory cytokine expression in human fetal membranes, decidua, cervix and myometrium before and during labour at term. Molecular Human Reproduction, Vol.9, No.1, pp. 41-45, ISSN 1360-9947

Osmers, R., Rath, W., Adelmann-Grill, B. C., Fittkow, C., Kuloczik, M., Szeverenyi, M., Tschesche, H. \& Kuhn, W. (1992) Origin of cervical collagenase during parturition. American Journal Obstetrics and Gynecology, Vol.166, No.5, pp. 1455-1460, ISSN $0002-$ 9378 
Pierdominici, M., Maselli, A., Colasanti, T., Giammarioli, A. M., Delunardo, F., Vacirca, D., Sanchez, M., Giovannetti, A., Malorni, W. \& Ortona, E. (2010) Estrogen receptor profiles in human peripheral blood lymphocytes. Immunological letters, Vol.132, No.1-2, pp. 79-85, ISSN 1879-0542

Prossnitz, E. R., Arterburn, J. B. \& Sklar, L. A. (2007) GPR30: A G protein-coupled receptor for estrogen. Molecular and Cellular Endocrinology, Vol.265-266, pp. 138-142, ISSN 0303-7207

Sahlin, L., Stjernholm-Vladic, Y., Roos, N., Masironi, B. \& Ekman-Ordeberg, G. (2008) Impaired leukocyte influx in cervix of postterm women not responding to prostaglandin priming. Reproductive Biology \& Endocrinology, Vol.6, pp. 36, ISSN 1477-7827

Salamonsen, L. A. \& Lathbury, L. J. (2000) Endometrial leukocytes and menstruation. Human Reproduction Update, Vol.6, No.1, pp. 16-27, ISSN 1355-4786

Scariano, J. K., Emery-Cohen, A. J., Pickett, G. G., Morgan, M., Simons, P. C. \& Alba, F. (2008) Estrogen receptors alpha (ESR1) and beta (ESR2) are expressed in circulating human lymphocytes. Journal of Receptors and Signal Transduction Research, Vol.28, No.3, pp. 285-293, ISSN 1079-9893

Segerer, S., Kammerer, U., Kapp, M., Dietl, J. \& Rieger, L. (2009) Upregulation of chemokine and cytokine production during pregnancy. Gynecologic and Obstetric Investigation, Vol.67, No.3, pp. 145-150, ISSN 1423-002X

Shim, G. J., Gherman, D., Kim, H. J., Omoto, Y., Iwase, H., Bouton, D., Kis, L. L., Andersson, C. T., Warner, M. \& Gustafsson, J. A. (2006) Differential expression of oestrogen receptors in human secondary lymphoid tissues. Journal of Pathology, Vol.208, No.3, pp. 408-414, ISSN 0022-3417

Siracusa, M. C., Overstreet, M. G., Housseau, F., Scott, A. L. \& Klein, S. L. (2008) 17betaestradiol alters the activity of conventional and IFN-producing killer dendritic cells. Journal of Immunology, Vol.180, No.3, pp. 1423-1431, ISSN 0022-1767

Smith, J. M., Shen, Z., Wira, C. R., Fanger, M. W. \& Shen, L. (2007) Effects of menstrual cycle status and gender on human neutrophil phenotype. American Journal of Reproductive Immunology, Vol.58, No.2, pp. 111-119, ISSN 1046-7408

Straub, R. H. (2007) The complex role of estrogens in inflammation. Endocrine Reviews, Vol.28, No.5, pp. 521-574, ISSN 0163-769X

Stygar, D., Masironi, B., Eriksson, H. \& Sahlin, L. (2007) Studies on estrogen receptor (ER) alpha and beta responses on gene regulation in peripheral blood leukocytes in vivo using selective ER agonists. Journal of Endocrinology, Vol.194, No.1, pp. 101-119.

Stygar, D., Wang, H., Vladic, Y. S., Ekman, G., Eriksson, H. \& Sahlin, L. (2001) Colocalization of oestrogen receptor beta and leukocyte markers in the human cervix. Molecular Human Reproduction, Vol.7, No.9, pp. 881-886, ISSN 1360-9947

Stygar, D., Wang, H., Vladic, Y. S., Ekman, G., Eriksson, H. \& Sahlin, L. (2002) Increased level of matrix metalloproteinases 2 and 9 in the ripening process of the human cervix. Biology of Reproduction, Vol.67, No.3, pp. 889-894, ISSN 0006-3363

Stygar, D., Westlund, P., Eriksson, H. \& Sahlin, L. (2006) Identification of wild type and variants of oestrogen receptors in polymorphonuclear and mononuclear leucocytes. Clinical Endocrinology (Oxf), Vol.64, No.1, pp. 74-81, ISSN 0300-0664 
Subramanian, M. \& Shaha, C. (2009) Oestrogen modulates human macrophage apoptosis via differential signalling through oestrogen receptor-alpha and beta. Journal of Cellular and Molecular Medicine, Vol.13, No.8B, pp. 2317-2329, ISSN 1582-4934

Thomson, A. J., Telfer, J. F., Young, A., Campbell, S., Stewart, C. J., Cameron, I. T., Greer, I. A. \& Norman, J. E. (1999) Leukocytes infiltrate the myometrium during human parturition: further evidence that labour is an inflammatory process. Human Reproduction, Vol.14, No.1, pp. 229-236, ISSN 0268-1161

Thongngarm, T., Jenkins, J. K., Ndebele, K. \& McMurray, R. W. (2003) Estrogen and progesterone modulate monocyte cell cycle progression and apoptosis. American Journal of Reproductive Immunology, Vol.49, No.3, pp. 129-138, ISSN 1046-7408

Tulchinsky, D. \& Hobel, C. J. (1973) Plasma human chorionic gonadotropin, estrone, estradiol, estriol, progesterone, and 17 alpha-hydroxyprogesterone in human pregnancy. 3. Early normal pregnancy. American Journal Obstetrics and Gynecology, Vol.117, No.7, pp. 884-893, ISSN 0002-9378

van den Heuvel, M. J., Xie, X., Tayade, C., Peralta, C., Fang, Y., Leonard, S., Paffaro, V. A., Jr., Sheikhi, A. K., Murrant, C. \& Croy, B. A. (2005) A review of trafficking and activation of uterine natural killer cells. American Journal of Reproductive Immunology, Vol.54, No.6, pp. 322-331, ISSN 1046-7408

Walker, V. R. \& Korach, K. S. (2004) Estrogen receptor knockout mice as a model for endocrine research. Institute of Laboratory Animal Research Journal, Vol.45, No.4, pp. 455-461, ISSN 1084-2020

Wang, H., Stjernholm, Y., Ekman, G., Eriksson, H. \& Sahlin, L. (2001) Different regulation of oestrogen receptors alpha and beta in the human cervix at term pregnancy. Molecular Human Reproduction, Vol.7, No.3, pp. 293-300, ISSN 1360-9947

Watson, R. W., O'Neill, A., Brannigan, A. E., Coffey, R., Marshall, J. C., Brady, H. R. \& Fitzpatrick, J. M. (1999) Regulation of Fas antibody induced neutrophil apoptosis is both caspase and mitochondrial dependent. FEBS Letters, Vol.453, No.1-2, pp. 6771, ISSN 0014-5793

Wira, C. R., Fahey, J. V., Ghosh, M., Patel, M. V., Hickey, D. K. \& Ochiel, D. O. (2010) Sex hormone regulation of innate immunity in the female reproductive tract: the role of epithelial cells in balancing reproductive potential with protection against sexually transmitted pathogens. American Journal of Reproductive Immunology, Vol.63, No.6, pp. 544-565, ISSN 1600-0897

Yovel, G., Shakhar, K. \& Ben-Eliyahu, S. (2001) The effects of sex, menstrual cycle, and oral contraceptives on the number and activity of natural killer cells. Gynecologic Oncology, Vol.81, No.2, pp. 254-262, ISSN 0090-8258

Yuan, M., Jordan, F., McInnes, I. B., Harnett, M. M. \& Norman, J. E. (2009) Leukocytes are primed in peripheral blood for activation during term and preterm labour. Molecular Human Reproduction, Vol.15, No.11, pp. 713-724, ISSN 1460-2407

Zaitsu, M., Narita, S., Lambert, K. C., Grady, J. J., Estes, D. M., Curran, E. M., Brooks, E. G., Watson, C. S., Goldblum, R. M. \& Midoro-Horiuti, T. (2007) Estradiol activates mast cells via a non-genomic estrogen receptor-alpha and calcium influx. Molecular Immunology, Vol.44, No.8, pp. 1977-1985, ISSN 0161-5890 
Zhao, X. J., McKerr, G., Dong, Z., Higgins, C. A., Carson, J., Yang, Z. Q. \& Hannigan, B. M. (2001) Expression of oestrogen and progesterone receptors by mast cells alone, but not lymphocytes, macrophages or other immune cells in human upper airways. Thorax, Vol.56, No.3, pp. 205-211, ISSN 0040-6376 


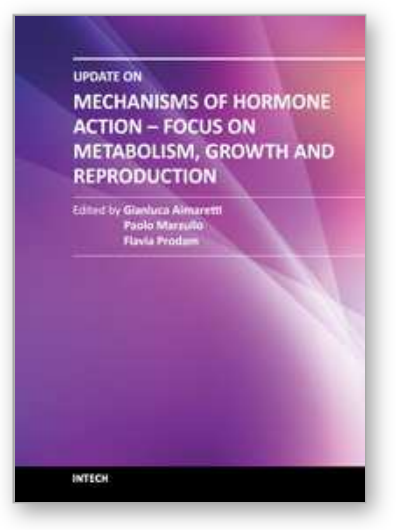

\section{Update on Mechanisms of Hormone Action - Focus on Metabolism, Growth and Reproduction}

Edited by Prof. Gianluca Aimaretti

ISBN 978-953-307-341-5

Hard cover, 470 pages

Publisher InTech

Published online 26, October, 2011

Published in print edition October, 2011

The purpose of the present volume is to focus on more recent aspects of the complex regulation of hormonal action, in particular in 3 different hot fields: metabolism, growth and reproduction. Modern approaches to the physiology and pathology of endocrine glands are based on cellular and molecular investigation of genes, peptide, hormones, protein cascade at different levels. In all of the chapters in the book all, or at least some, of these aspects are described in order to increase the endocrine knowledge.

\section{How to reference}

In order to correctly reference this scholarly work, feel free to copy and paste the following:

Chellakkan Selvanesan Blesson (2011). Estrogen Receptors in Leukocytes - Possible Impact on Inflammatory Processes in the Female Reproductive System, Update on Mechanisms of Hormone Action - Focus on Metabolism, Growth and Reproduction, Prof. Gianluca Aimaretti (Ed.), ISBN: 978-953-307-341-5, InTech, Available from: http://www.intechopen.com/books/update-on-mechanisms-of-hormone-action-focus-onmetabolism-growth-and-reproduction/estrogen-receptors-in-leukocytes-possible-impact-on-inflammatoryprocesses-in-the-female-reproductiv

\section{INTECH}

open science | open minds

\section{InTech Europe}

University Campus STeP Ri

Slavka Krautzeka 83/A

51000 Rijeka, Croatia

Phone: +385 (51) 770447

Fax: +385 (51) 686166

www.intechopen.com

\section{InTech China}

Unit 405, Office Block, Hotel Equatorial Shanghai

No.65, Yan An Road (West), Shanghai, 200040, China

中国上海市延安西路65号上海国际贵都大饭店办公楼 405 单元

Phone: +86-21-62489820

Fax: $+86-21-62489821$ 
(C) 2011 The Author(s). Licensee IntechOpen. This is an open access article distributed under the terms of the Creative Commons Attribution 3.0 License, which permits unrestricted use, distribution, and reproduction in any medium, provided the original work is properly cited. 